\title{
頭頸部癌に対する化学療法の役割
}

\author{
犬山征 夫
}

要旨 : 頭頸部癌に対する化学療法の役割について1）全国 15 施設による共同研究としての頭頸部癌に対 するUFT の第 2 相試験, 2) 上顎洞癌に対する Neo-adjuvant chemotherapy を組み入れた集学的治療, 3）UFT と放射線治療の同時併用の検討，4）頭頸部癌に対するUFTによる Adjuvant chemotherapyの 無作為比較試験, 5) Intergroupによる上咽頭癌に対する Adjuvant chemotherapy，6）姑息的治療とし ての化学療法, 7) S-1の前期臨床第 2 相試験について述べた。

キーワード: UFT, Neo-adjuvant chemotherapy, 放射線治療と化学療法の同時併用, Adjuvant chemotherapy, S-1

\section{Summary The role of chemetherapy for head and neck cancer :}

Yukio Inuyama. Department of Otolaryngology, Hokkaido University School of Medicine.

The following topics were explained in luncheon lecture. 1) A phase II study of UFT for head and neck cancer in Japan, 2) Multimodal treatment incorporating neo-adjuvant chemotherapy for maxillary sinus carcinoma, 3) Clinical trial of concurrent UFT and radiotherapy, 4) A prospective randomized trial of adjuvant chemotherapy with UFT for head and neck cancer, 5) Adjuvant chemotherapy for nasopharyngeal carcinoma by Intergroup, 6) Chemotherapy for palliation for unresectable or recurrent head and neck cancer, 7) Early phase 2 study of UFT for head and neck cancer in Japan.

Key words : UFT, Neoadjuvant chemotherapy, concurrent radiochemotherapy and chemotherapy, adjuvant chemotherapy, S-1

\section{1. 頭頸部癌に対するUFT の第 2 相試験}

UFT は tegafur と uracil $1: 4$ のモル比で配 合した経口抗癌剤である。本薬剤の臨床試験は 1982 年 4 月から 1984 年 3 月までの 24 カ月間に全 国 10 施設による共同研究 ${ }^{1)}$ とて行われた。登録 例数は 84 例であったが, 評価可能例数は 60 例で ある。投与方法はUFT カプセル剂を 1 日 $600 \mathrm{mg} /$ day 連日経口投与とし, 可能な限り 4 週間以上継 続することとした。

\footnotetext{
* 北海道大学医学部耳鼻咽喉科学教室
}

抗腫瘍効果であるが, 60 例中 CR 8 例, PR 10 例で奏効率 $30 \%$ であった。効果の持続期間は平均 4.7 カ月であり, 最長 11 カ月以上であった。組織 型別効果では, 扁平上皮癌では 55 例中, CR 7 例, PR 10 例で奏効率 $30.9 \%$ であった。また未分化癌 の 1 例において CR を認めたが, 腺癌の 2 例, 腺 様囊胞癌の 1 例はいずれも NCであり, 粘表皮癌 の 1 例は PD であった。

副作用についてみると, 評価可能であった 67 例中 27 例に副作用を認め, 発現率は $40.3 \%$ であっ た。食欲不振は $32.8 \%$ でもとも頻度が高く, 次 いで悪心・嘔吐 $16.4 \%$, 口内炎 $7.5 \%$, 下痢 $6.0 \%$ 
犬山征夫 : 頭頸部癌に対する化学療法の役割

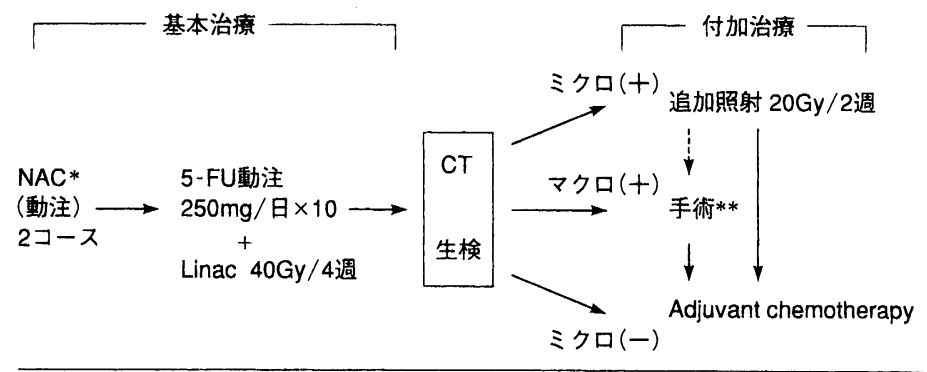

*CDDP+PEP 22例，THP+CDDP+PEP 5例, CDDP+5-FU 1例

**上頻温存を目的とした部分切除およびsalvage surgeryを目的とした拡大手術+再建術 を含む

図 1 上顎洞癌に対する neo-adjuvant chemotherapyを組み入れた集学的治療

などの順であり，概して副作用は軽微であった。 しかし，83歳の上顎洞癌症例に対し， $600 \mathrm{mg} /$ 日 にて 23 日間投与したところ，腫瘍の著明な縮小 を認めたものの, 白血球減少 (nadir $700 / \mathrm{mm}^{3}$ ), 血小板減少 (nadir $6.5 \times 10 / \mathrm{mm}^{3}$ ), 食欲不振, 悪心・嘔吐，下痢，口内炎など重篤な副作用を認 めた。

\section{2. 上顎洞癌に対する Neo-adjuvant chemo- therapy (NAC)}

慶大耳鼻咽喉科では 1982 年 5 月から 1987 年 4 月までの 5 年間に 28 例の上顎洞癌に対して NAC を組み入れた集学的治療 ${ }^{2}$ を行った。組織型は全 例扁平上皮癌で, $\mathrm{T}$ 分類については, $\mathrm{T} 1: 0, \mathrm{~T} 2$ :

2, T3 : 17, T4: 9 例で，全例 N0，M0であった。 集学的治療の実際を図 1 に示す。NAC は2 コー スを原則とした。NACは CDDP+PEPを主体と した。NACの効果は 28 例中, CR 12 例, PR 12 例, NC 4 例で奏効率は $86 \%, \mathrm{CR}$ 率 $43 \%$ であっ た。一方，5-FU 動注と照射の同時併用後の効果 は 28 例中, CR 19 例, PR 8 例, NC 1 例で奏効 率 $96 \%$ ，CR 率 68\%であった。

遠隔成績では 5 年, 10 年生存率（overall）は 各々 $54 \% ， 45 \%$ であった。また 5 年，10 年の無再 発生存率はともに $40 \%$ であった。一方，T分類別 5 年生存率では T2：100\%, T3：65\%と良好であ るが，T4は残念ながら 0 \%であった。

一方, 上顎の温存率では治療終了時点での上顎 温存率は $79 \%$ であり，さらに 10 年生存者の $67 \%$ に上顎が温存されていた。すでに述べたように $\mathrm{T} 4$ の成績は極めて不良で, 約半数は腫瘍が頭蓋
表 1 年代別にみた 5 年生存率と上顎温存率

\begin{tabular}{|c|c|c|c|}
\hline 年代別グループ & 例数 & $\begin{array}{c}5 \text { 年生存率 } \\
(\%)\end{array}$ & $\begin{array}{c}\text { 上額温存率 } \\
(\%)^{*}\end{array}$ \\
\hline 第1群 (1957 1966) & 96 & 22 & 11 \\
\hline 第 2 群（1967 1973） & 70 & 40 & 15 \\
\hline 第 3 群 (1974 1981) & 56 & 42 & 64 \\
\hline 第 4 群 (1982 1987) ** & 28 & 54 & $(45)^{* * *} 79(67)^{*}$ \\
\hline
\end{tabular}

底に進展して死亡した（表 1)。

1992 年 4 月から 1996 年 3 月までの 4 年間，厚 生省がん研究助成金により，「頭頸部がんの境界 領域における新しい治療法の開発と評価に関する 研究」の班長を務める機会に恵まれ，8 施設の協 力で 119 例の鼻副鼻腔悪性腫瘍に頭蓋底手術が行 われ，5年生存率 $48 \%$ という優れた成績 ${ }^{3)}$ が得ら れた。とりわけ, 腺様菙胞癌, 骨軟部組織悪性腫 瘍, 嗅神経芽細胞腫では $60 \%$ を越える 5 年生存率 が得られた（図2）。

\section{UFT と照射の同時併用}

慶大耳鼻咽喉科では 1983 年から 1987 年の間に 頭頸部癌 29 例に対してUFT と照射の同時併用 ${ }^{4)}$ を試みた。その結果 29 例中, CR 16 例, PR 10 例で奏効率 $90 \%, \mathrm{CR}$ 率 $55 \%$ という成績が得られ た。既治療の有無別では，未治療例は 22 例中， CR 12 例, PR 8 例で奏効率 $91 \%$, また再発例で は 7 例中, CR 4 例, PR 2 例で奏効率 $86 \%$ で未 治療例と同等の成績が得られた。しかし, 副作用 としては局所毒性としての口内炎があげられる。 従って薬用量を上手にコントロールすることが重 


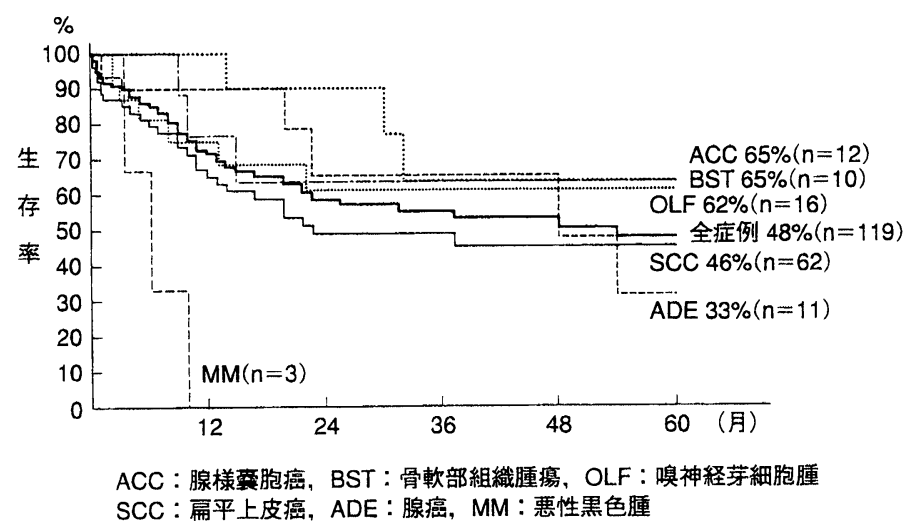

図 2 鼻副鼻腔悪性腫瘍の頭蓋底進展例に対する頭蓋底手術例の生存曲線

要と考えられた。

\section{4. 頭頸部癌に対する UFT による術後の Ad- juvant chemotherapy $の$ 無作為化比較試験}

本研究 ${ }^{5)}$ は 1987 年 9 月より 1990 年 3 月までの 2 年 6 カ月の間に全国 67 施設による共同研究とし て行われた。登録例は 424 例であるが，適格例は 398 例で UFT 投与群および非投与群それぞれ 199 例ずつ割り付けられた。UFT 投与群は根治治療 終了後，30日間腫瘍消失を確認した後 7 日以内に UFT $300 \mathrm{mg} /$ 日を 1 年間連日経口投与した。ただ し体重が $60 \mathrm{~kg}$ 以上の症例では $400 \mathrm{mg}$ も可とした。 結果であるが, 全症例の根治切除後の 3 年時点 での消息判明率は $93.0 \%$ であり，3 年生存率は UFT 投与群 $77.9 \%$, 非投与群 $72.9 \%$ であり，両 群間に有意差は認められなかった。また 3 年無再 発生存率はUFT 投与群 $73.4 \%$, 非投与群 $66.2 \%$ であり，両群間に有意差は認められなかった。3 年間の観察期間中にみられた初回再発部位を原発 巣, 頸部リンパ節, 遠隔部位のカテゴリーに分け て集計すると, 同時に複数の部位に再発が認めら れた場合は，より遠位のカテゴリーに帰属させ集 計を行った。その結果，遠隔転移は非投与群では 199 例中 13 例であった。これらの症例について 3 年遠隔再発率を算出すると，非投与群は $14.6 \%$ に対して，UFT 投与群は 7.9\%であり，UFT 群は $\mathrm{p}=0.034$ で有意に低率であった。さらに，Coxの ハザードモデルにより遠隔転移に関与すると考え られる性別，年齢，PS， stage，原発部位の 5 因 子の偏りを補正した結果においても，UFT 投与
群は非投与群に比し，有意に遠隔再発を抑制した $(\mathrm{p}=0.038)$ 。

\section{Intergroup による上咽頭癌に対する Adju- vant chemotherapy}

この studyにはRTOG, SWOG, ECOG， NCOG など 6 つの group が参加している6)。この group には 696 例が登録され，499 例が randomize された。対象は扁平上皮癌で, 部位は口腔, 中咽頭, 下咽頭, 喉頭の 4 部位である。病期分類 は下咽頭癌は II , III， IV 期であるが，他の部位は III， IV 期で，いずれも M0であり，しかも resectable な症例である。術後の病理組織学的所 見で 2 つの group に分けられる。すなわち high risk group（リンパ節の被膜外進展があるもの, 原発巣の surgical margin が<5 mm, あるいは margin に carcinoma-in-situのあるもの）と low risk group（リンパ節の被膜外進展のないも の，または原発巣の surgical margin が $\geqq 5 \mathrm{~mm}$ のもの)である。

化学療法は CDDP $100 \mathrm{mg} / \mathrm{m}^{2}$ iv 第 1 日, $5-\mathrm{FU}$ $1,000 \mathrm{mg} / \mathrm{m}^{2} \operatorname{civ} 24$ 時間, 第 $1 \sim 5$ 日以上を 1 コー スとして 3 週間隔で 3 コース行う。放射線治療は low riskでは 50〜54Gy, high risk では 60Gy 照 射される。以上より 446 例が放射線単独治療に, 222 例が放射線治療，化学療法に割り付けられた。

結果であるが, loco/regional recurrence が起 こるまでの期間, 4-year failureでは両群間に有 意差はみられなかった。さらに 4 年生存率 (over all)，4年無再発生存率ともに両群間に有意差は 
認められなかった。これに対して，遠隔転移の発 生率をみると，照射単独群では $23 \%(51 / 224)$ で あるのに対し，照射 $\rightarrow$ 化学療法では $15 \%$ （33/ 222）と低く, 両群間に有意の差が認められた（ $p=$ $0.02)$ 。

\section{6. 姑息的治療としての化学療法}

1）切除不能局所進行癌 · 再発癌

筆者が 1975 年から 1996 年までの過去 21 年間 に慶大および北大で治療を行った 171 例について の成績 ${ }^{7)}$ を述べる。これらの症例は根治手術や根 治照射を受けた原発巣および頸部リンパ節転移の 再発癌が主体であり，化学療法のみが残された治 療であった症例，再発後の手術拒否例，また一部 に未治療の進行癌も含まれている。化学療法の内 容は表 2 に示す通りであるが，各症例について予 後に影響を与えたと考えられる regimen，または 主体となった regimen を示している。その成績を みると, 1 年以上 2 年未満の生存は 31 例, 2 年以 上 3 年末満の生存は 9 例, 3 年以上 4 年未満の症 例は 4 例, 4 年以上 5 年未満の症例は 1 例である。 また 5 年以上の生存例は 4 例のみであった。

一方，1987 年に，これらの症例のうち 109 例に
ついて医師側からみた化学療法によるQOL につ き検討した ${ }^{8)}$ 。その結果，109 例中 39 例 $(36 \%)$ にQOL の改善が認められた。すなわち 2 例は治 癒（当時, 各 7 年および 8 年生存）により社会復 帰しており，理想的な状態である。また 1 例は担 癌状態であるが, 投薬により, 腫瘍の増大が抑制 されており（5年生存中）通院しつつ社会復帰し ている。一方, 化学療法により performans status が改善したため, 通院加療が可能で, 自宅 で十分日常生活が楽しめ，かつ延命中または延命 効果があった例が 30 例でもっとも多かった。そ の他, performans statusの改善と延命効果を認 めたが退院には至らなかった例が 2 例, 疼痛の軽 減など自覚症状の改善のみ認められた例が 4 例で あった。

\section{S-1 の前期臨床第 2 相試験}

S-1 は tegafur（FT）に，2 種類の modulator である 5-chloro-2, 4-dihydroxypyridine (CDHP) と potassium oxonate (Oxo) をモル 比で FT : CDHP : OXo=1:0.4:1に配合した新 規経口抗癌剤である。

本臨床試験は 1994 年 1 月から 1996 年 3 月まで

表 2 頭頸部局所進行癌・再発癌に対する化学療法単独治療の遠隔成績

\begin{tabular}{|c|c|c|c|c|c|c|c|c|c|c|c|c|c|}
\hline \multirow{2}{*}{ 化学療法 } & \multirow{2}{*}{ 例数 } & \multicolumn{12}{|c|}{ 年数 } \\
\hline & & 1 & 2 & 3 & 4 & 5 & 6 & 7 & 12 & 13 & 14 & 15 & 16 \\
\hline BLM,MMC(BM) & 20 & & 1 & 2 & & & & & & & & & \\
\hline PEP & 4 & 1 & & & 1 & & & & & & & & \\
\hline VCR,MTX,BLM(VMB) & 4 & 1 & & & & & & & & & & & \\
\hline Price-Hill & 2 & & & & & & & & & & & & \\
\hline VCR,MTX,BLM,MMC(VMBM) & 18 & 2 & & 1 & & & & & & & & & \\
\hline CDDP & 7 & 1 & & & & & & & $1 \#$ & & & & $1^{*}$ \\
\hline UFT & 27 & 10 & 3 & & & & $1^{* *}$ & & & & & & \\
\hline CDDP,PEP(CP) & 17 & 1 & 3 & 1 & & & & & & & & & \\
\hline VDS,MTX,PEP(VMP) & 11 & 2 & & & & & & & & & & & \\
\hline $\operatorname{ADM}(T H P), C D D P, P E P(A C P)$ & 10 & 1 & & & & & & & & & & & \\
\hline VCR,CDDP,PEP(VPCP) & 20 & 5 & 1 & & & & & & & & & & \\
\hline CDDP,5-FU(CF) & 6 & 1 & 1 & & & & & & & & & & \\
\hline nedaplatin(254-S) & 9 & 2 & & & & & & & & & & & \\
\hline $\mathrm{VMP} \rightarrow \mathrm{CF}$ & 10 & 2 & & & & & & & & & & & \\
\hline CDDP,ETP,MMC(PEM) & 3 & 1 & & & & & & & & & & & \\
\hline \multirow[t]{2}{*}{ UFT,MMC(UFT-M) } & 3 & 1 & & & & $1^{*}$ & & & & & & & \\
\hline & 171 & 31 & 9 & 4 & 1 & 1 & 1 & & 1 & & & & 1 \\
\hline
\end{tabular}


の間に全国 15 施設による共同研究 ${ }^{9)}$ として行われ た。登録症例は 27 例（扁平上皮癌 25 例）である。 このうち原発不明の頸部腫瘤症例を不適格例とし たため, 適格例は 26 例である。26 例中, 副作用 のため 21 日未満で投与を中止した 2 例を不完全 例とし，24例を完全例とした。本剤の 1 日 2 回 28 日間連日投与法は, 臨床第 1 相試験の結果 ${ }^{10)}$ に基 づいて, 最大許容量は $75 \mathrm{mg} /$ body $\times 2 /$ day 以上 $100 \mathrm{mg} /$ body $\times 2 /$ day 未満が推奨された。

治療成績は適格例 26 例中 CR 1 例, PR 11 例 で奏効率は $46.2 \%(12 / 26)$ であった。既治療の 有無別にみると，未治療例では，奏効率 $60.0 \%$ (6/10)，既治療例では奏効率 $37.5 \%$ （6/16）であっ た。

臨床検査值の異常としては血色素量減少, 白血 球減少, 好中球減少, 赤血球減少, ヘマトクリッ 卜值減少, 血小板減少などであり, その多くは一 過性であった。一方, 副作用では食欲不振, 悪心 嘔吐, 皮䖉症状, 口内炎などであった。grade 4 の副作用はみられなかった。

以上より本剂は頭頸部癌に対して強い抗腫瘍効 果と消化管毒性の軽減化を実現した新規経口抗癌 剤として期待される結果が得られた。

\section{文献}

1) 犬山征夫, 竹田千里, 三宅浩郷, 他 : 頭頸部癌に対 する UFT の Phase II Study. 癌と化学療法 12: 479-484, 1985.

2）犬山征夫・編著 : 第 8 章 $\mathrm{Neo}^{-}$adjuvant chemoth erapy, 頭頸部癌治療における化学療法の役割. pp. 157-216, 東京医学社, 東京, 1997.

3）犬山征夫 - 監修: 厚生省班研究における頭蓋底手術 および上縦隔郭清の統計的観察。頭頸部がんの境界 領域における治療法の最新の進歩, pp 124-131，協 和企画通信, 東京, 1996.

4）犬山征夫, 藤井正人, 田中寿一, 他 : 頭頸部癌にお ける放射線治療と化学療法併用の効果と問題点. 癌 と化学療法 $15: 1621-1627,1988$.

5）佃 守, 堀内正敏, 犬山征夫, 他: 無作為化比較試 験による頭頸部癌補助化学療法における UFT の有 用性検討. 癌と化学療法 21:1169-1177, 1994.

6) Laramore GE, Scott CB, Al-Sarraf M, et al : Adjuvant chemotherapy for resectable squamous cell carcinomas of the head and neck. Int J Radiat Oncol Biol Phys 23 : 885886, 1992.

7) Inuyama $Y$, Fukuda S, Furuta $Y$, et al: The role of chemotherapy in the treatment of head and neck cancer. Jpn J Cancer Chemother 24(Suppl 1) : 52-59, 1997.

8）犬山征夫, 藤井正人, 田中寿一, 他：Quality of lifeを考慮に入れた頭頸部進行癌・再発癌に対する 化学療法の延命効果について.耳鼻 $34: 1220$ $1227,1988$.

9) 犬山征夫, 木田亮紀, 佃 守, 他 : 頭頸部癌に対す る S-1 の前期第 II 相臨床試験. 癌と化学療法 25 : 1151-1158, 1998.

10）田口鐵男, 犬山征夫, 金丸龍之介, 他 : $\mathrm{S}-1$ の臨床 第 I 相試験. 癌と化学療法 $24: 2253-2264,1997$. 